\title{
Investigation of Neuroprotective and Antiparkinson's Activity of Citrullus colocynthis Fruit
}

\author{
Fariya Nimra*, Nishat Fatima \\ Department of Pharmacology, Shadan Women's College of Pharmacy, Jawaharlal Nehru Technological \\ University, Hyderabad, Telangana, India - 500004.
}

\section{ABSTRACT}

Citrullus colocynthis (L.) Schrad (Cucurbitaceae) is a desert watermelon that is extensively widespread around the world. Colocynth or Bitter Apple is the popular name for the fruit of $C$. colocynthis. Cucurbitacins, colocynthosides, and flavonoids glucosides were found in the fruit, according to reports. This herb has been used for centuries to cure diabetes, abortifacients, epilepsy, jaundice, and asthma. $C$. colocynthis was investigated for its anti-action Parkinson's in Wistar rats using in vivo behavioural and biochemical experiments. The block test and actophotometer were used to investigate the effects of $C$. colocynthis on catalepsy and mobility, respectively. In haloperidol-treated animals, the effect of $C$. colocynthis on dopamine levels and protective anti-oxidant enzymes such as malondialdehyde (MDA) and superoxide dismutase (SOD) in brain tissue were studied. The $C$. colocynthis considerably reduced the effects of haloperidol on vacuous chewing movements, tongue protrusion, orofacial burst, and catalepsy. When compared to haloperidol treated animals, $C$. colocynthis effectively restored dopamine and SOD levels in the brain while inhibiting MDA levels. The current study suggested that oxidative stress may play a key role in haloperidol induced Parkinson's activity, and $C$. colocynthis has promising role in management of Parkinson's disease therapy.

Keywords: Citrullus colocynthis, curcurbitacin, Parkinson disease, catalepsy, antioxidants, MDA.

\section{INTRODUCTION}

Parkinson's disease (PD) is a progressive neurological ailment that damages the dopamineproducing nerve cells in the brain as people get older. ${ }^{1}$ Dopamine is a neurotransmitter that is well known for relaying chemical messages and controlling the body's soft controls and coordinated brain activities. Most dopaminergic neuronal cells in the substantia nigra pars compacta ( $\mathrm{SNpc}$ ) of the brain die, resulting in initiation of the symptoms of PD disorder. ${ }^{2,3} \mathrm{PD}$ is the second most common illness, affecting children, young adults, and those over the age of
60. Muscle stiffness, tremors, dementia, sleeplessness, ansonia, bowel problems, incontinence, and abnormalities in speech and gait are some of the symptoms. ${ }^{4,5}$ In India, over one million cases are reported each year, while the global incidence is estimated to be 31 to 328 per 100,000 people. Parkinson's disease affects fewer women than it does men. Parkinson's disease is thought to impact 1-2 people out of every 1000. Treatments can only assist to ease symptoms after a diagnosis; there is no cure. 6

Dopamine neuronal loss in the brain occurs mostly with time, resulting toward a worsening of

*Corresponding Author: fariafaiz55@gmail.com 
disease symptoms. Oxidative stress has been demonstrated to interfere with dopamine metabolism, resulting in PD.7 The development of reactive oxygen species (ROS) as a result of oxidative damage leads to neuronal death. When the body's natural antioxidant system is overwhelmed by free radical generation, oxidative stress occurs, and an exogenous antioxidant can help the body cope with the negative effects of oxidative stress. These findings made it clear that antioxidants, in addition to other preventive agents, should be used as a therapeutic intervention in Parkinson's disease.8-10 The current medication therapies for Parkinson's disease include a range of negative effects. As a result, herbal remedies should be investigated as an alternate treatment option. ${ }^{11}$

Herbal supplements have long been utilized to treat Parkinson's disease patients across the world. Plants have secondary metabolites that include phenolics, terpenes, and nitrogencontaining groups. ${ }^{12}$ Many polyphenols have been discovered to have the ability to pass the bloodbrain barrier (BBB), allowing medicines or chemicals to be absorbed selectively. Several modern supplements and literatures recommend using herbal supplements in conjunction with medication therapy to treat a variety of diseases. The use of natural metabolites from plants as a treatment option for Parkinson's disease patients might be a viable option. ${ }^{13,14}$

Citrullus colocynthis (L.) Schrad is a perennial herbaceous plant in the Cucurbitaceae family that resembles a common watermelon and is extensively spread in arid locations across the world. Colocynth or Bitter Apple is the popular name for the fruit of $C$. colocynthis.15 Alkaloids, tannins, saponins, flavonoids, unsaturated sterols, oxygenated terpenes, sterols, and steroids were found in a hydro-methanolic extract of the fruit. Fruit extracts contained cucurbitacins, colocynthosides, and flavonoids glucosides such as isovitixin, isorintin, and isosapanorin. ${ }^{16}$ This plant is used in traditional Iranian medicine (TIM) for the treatment of diabetes, abortifacients, epilepsy, jaundice, and asthma due to its many pharmacologic actions.17,18 Many additional pharmacological qualities have been described, including diuretic, anti-hyperlipidemic, anticancerous, antioxidant, and anti-microbial. ${ }^{19}$

In this study, the fruit of $C$. colocynthis was investigated for its anti-Parkinson's activity using in-vivo biochemical and behavioural experiments in albino Wistar rats, based on the features indicated previously in the literature.

\section{MATERIAL AND METHODS}

\subsection{Chemicals and Reagents}

Haloperidol and carbidopa was procured from Citi Neurocentre, Hyderabad, India. The remaining chemicals used in the experiment have been of analytical grade.

\subsection{Experimental Animal}

Wistar albino rats, weighing 150-230g were brought from Sai Nath Agencies, Hyderabad, India and acclimatized for 14 days in animal house of Shadan Institute of Medical Sciences (SIMS), Hyderabad, India. Before the experiment, the animals were housed in polypropylene cages under characteristic light-dark cycle in standard research facility conditions. They were allowed standard diet and water ad libitum till the exploratory period. The experiments protocol was approved by Institutional Animal Ethical Committee (IAEC) of SIMS (Reg No. 282/PO/Bt/S2000/CPCSEA) and CPCSEA norms were followed during experiments. The approved protocol number for the purpose work is IAEC03/SES/2019/006. Between 9 and 17 hours, behavioural evaluations were conducted at room temperature in a peaceful diffusely lit environment.

\subsection{Collection and Extraction of Fruit}

The fruits of Citrullus colocynthis (L.) Schrad was collected from the herbal garden of Anantapur, Andhra Pradesh, India. Dr. A. Madhav Shetty, Department of Botany, Sri Venkateswara University, Tirupati, India has authenticated the gathered plant. The department was placed with a Herbarium voucher numbered 1215. 
The pulp from fresh fruits was homogenized and dried in the shade. To prevent deterioration during thorough drying, $0.5 \%$ sodium benzoate was applied. After drying, a dark brownish red powder mass was ground with a grinder. In a soxhlet device, the dried C. colocynthis fruit pulp was extracted with water (AECC) and ethanol (EECC). These concentrations were then used for qualitative phytochemical analysis and pharmacological activity evaluation. ${ }^{20}$

\subsection{Qualitative Phytochemical Analysis}

With the help of procedures outlined by Gul et al., 2017, preliminary qualitative phytochemical screening was done to monitor the presence of various chemical groups such as alkaloids, polyphenols, aromatic oils, tannins, phlobatanins, amino acids, flavonoids, terpenoids, saponins, sterols, carbohydrates, protein, and glycosides. ${ }^{21}$

\subsection{Toxicity Studies}

The toxicology experimental investigation of ethanolic and aqueous fruit extracts of $C$. colocynthis was conducted on Wistar albino rats using extracts in compliance with OECD guideline number 423 . Animals were given the aqueous and ethanolic extracts orally at dosages of 5, 50, 300, and $2000 \mathrm{mg} / \mathrm{kg}$ and observed for 24 hours, 48 hours, and 14 days after receiving the doses to check for mortality. The C. colocynthis was determined to be safe at all dosages, with no death rates seen when the ethanolic and aqueous extracts were taken orally. ${ }^{22,23}$

\subsection{Experimental Protocol}

The Wistar albino rats were randomly separated into seven groups, each with six animals. The first group was normal control group, received 0.9\% saline p.o., the second group was disease control and received haloperidol $1 \mathrm{mg} / \mathrm{kg}$ b.w. i.p., the third group was standard control and received carbidopa $125 \mathrm{mg} / \mathrm{kg}$ b.w. i.p., the fourth and fifth groups were test groups and received 200 and $400 \mathrm{mg} / \mathrm{kg}$ b.w. of aqueous extracts of $C$. colocynthis (AECC), sixth and seventh groups were test groups which received 200 and $400 \mathrm{mg} / \mathrm{kg}$ b.w. of ethanolic extracts of $C$. colocynthis (EECC). All of the groups were given the above treatment for 14 days. ${ }^{24}$

\subsection{Estimation of Behavioral Parameters \\ 2.7.1 Orofacial Dyskinesia}

Rats were put in a Plexiglas observation box $(22$ $\mathrm{cm} \times 22 \mathrm{~cm} \times 22 \mathrm{~cm}$ ) for a 10-minute habituation period after being given haloperidol. For a total of 5 minutes, all rats were monitored. According to Cousins, an investigator who was unknown to the treatment counted the number of vacuous chewing motion (VCM), orofacial burst (OB) and tongue protrusion (TP). ${ }^{25}$

\subsubsection{Catalepsy by Block Method}

A wooden block method was used to test the cataleptic behaviour in haloperidol treated animals. The rats were initially put on the table and softly nudged or stroked on the back in this technique. First, a cataleptic score of 0.5 was assigned to the rat's inability to move. Secondly, the rat's front paws were alternatively put on a 3 $\mathrm{cm}$ high wooden block. If rats failed to adjust their posture in 15 seconds, a score of 0.5 for each paw was given and applied to the first step's score. The rat's front paws were then simultaneously put on a $9 \mathrm{~cm}$ high wooden block. Finally, if rats unable to restore their posture after 15 seconds, they were given a cataleptic score of one for each paw, which was added to the scores from the first and second steps. Any animal's cut-off score was 3.5, which showed complete catalepsy. 26,27

\subsubsection{Locomotor Activity}

After tremors, akinesia, and muscle stiffness were assessed, locomotor activity was assessed using an actophotometer. The device is made up of photoelectric cells that are linked together in a circuit with a counter. A count was kept for 10 minutes when the animal cut off the light beam landing on the photocell. ${ }^{28}$

\subsection{Estimation of Biochemical Parameters}

The animals were decapitated at the end of the study, shortly after the behaviour tests. The brain was extracted and weighted after being cleaned with isotonic saline. In $0.1 \mathrm{M}$ phosphate buffer, a $10 \%(\mathrm{~W} / \mathrm{V})$ tissue homogenate was produced $(\mathrm{pH}$ 7.4). The postnuclear fraction for the catalase (CAT) assay was produced by centrifugation of the 
homogenate at $1000 \mathrm{~g}$ for $20 \mathrm{~min}$ at $4^{\circ} \mathrm{C}$ (Remi-C30, Remi Industries Ltd., Mumbai, India); for other enzyme assays, centrifugation was at $12000 \mathrm{~g}$ for $60 \mathrm{~min}$ at $4^{\circ} \mathrm{C}$. For the tests, an Elico Biospectrophotometer-BL200 was employed.29

\subsubsection{Estimation of Dopamine (DA)}

In HCl-butanol solution (1:10 for $1 \mathrm{~min}$ ), rat brain tissue was homogenized. For ten minutes, the homogenate was centrifuged at $3000 \mathrm{rpm} .1 \mathrm{ml}$ of aliquot supernatant was added to the centrifuge tube containing hexane $(2.5 \mathrm{ml})$ and $0.1 \mathrm{M} \mathrm{HCl}$ $(0.3 \mathrm{ml})$. At $0^{\circ} \mathrm{C}$, the aqueous phase $(0.2 \mathrm{ml})$ was used to perform the DA experiment. $0.4 \mathrm{M} \mathrm{HCl}$ $(0.05 \mathrm{ml})$ and sodium acetate buffer, $\mathrm{pH}$ 6.9, were added to the aqueous phase $(0.2 \mathrm{ml})$, followed by $0.1 \mathrm{M}$ in ethanol-iodine solution $(0.1 \mathrm{ml})$ for oxidation. After 2 minutes, a $0.1 \mathrm{ml}$ solution of sodium sulphite was added to terminate the reaction, followed by addition of acetic acid (0.1 $\mathrm{ml})$. For 6 minutes, the solution was heated to $100^{\circ} \mathrm{C}$. The spectrofluorimeter read the excitation and emission spectra at $330-375 \mathrm{~nm}$. The tissue blanks were made by adding the oxidation step's components in reverse order (iodine after sodium sulphite). ${ }^{30}$

\subsubsection{Estimation of Malondialdehyde (MDA)}

$1 \mathrm{ml}$ tissue homogenate, $0.2 \mathrm{ml}$ sodium lauryl sulfate solution, and $1.5 \mathrm{ml}$ each of thiobarbituric acid and acetic acid were used to make a $5 \mathrm{ml}$ solution. This was incubated for a few minutes before being heated in a water bath for 30 minutes. To extract the chromogen, n-butanol pyridine mixture was used and centrifuged for 10 minutes at $4000 \mathrm{rpm}$. The organic layer's absorbance was measured at $532 \mathrm{~nm}$. MDA concentration was expressed in nanomoles per milligram of protein. ${ }^{31}$

\subsubsection{Estimation of Superoxide Dismutase (DA)}

The activity of SOD was determined at $560 \mathrm{~nm}$ using Kono's approach from 1978. The reaction was performed by mixing hydroxylamine hydrochloride with nitroblue tetrazolium chloride (NBT) and postnuclear portion of brain homogenate in a reaction mixture. The results were represented as a percentage of NBT decrease inhibition. ${ }^{32}$

\subsection{Statistical Analysis}

The mean and standard error of the mean (SEM) were used to express all of the data. The computer-based fitting tool Graph Pad Prism version 5.0 (Graph Pad softaware, Inc., CA, USA) was used to examine statistical significance using one way ANOVA followed by Tukey's multiple comparison test. Statistical significance was defined as a $P$ value of less than 0.05 .

\section{RESULTS}

\subsection{Phytochemical Screening}

Phytochemical screening of the different extracts of $C$. colocynthis fruit showed the presence of the following phytochemical compounds (Table 1).

Table 1: Phytochemical compounds present in Citrullus colocynthis

\begin{tabular}{ccc}
$\begin{array}{c}\text { Phytochemical } \\
\text { Compounds }\end{array}$ & $\begin{array}{c}\text { Aqueous } \\
\text { Extract }\end{array}$ & $\begin{array}{c}\text { Ethanolic } \\
\text { Extract }\end{array}$ \\
Tannins & + & + \\
Phenols & + & ++ \\
Alkaloids & ++ & +++ \\
Saponins & + & ++ \\
Terpenoids & + & + \\
Flavonoids & ++ & +++ \\
Steroids & + & ++ \\
Carbohydrates & + & + \\
Glycosides & + & + \\
Saponin & + & ++ \\
Protein & + & + \\
\hline
\end{tabular}

$(+)=\operatorname{good} ;(++)=$ moderate $(+++)=$ excellent

\subsection{Effect of $C$. colocynthis on Orofacial}

\section{Dyskinesia}

The frequency of VCM, TP, and OB was significantly $(P<0.001)$ higher in the disease control group following the treatment with haloperidol when compared to the normal control group. When compared to the disease control group, treatment with standard drug, AECC and EECC extracts at 200 and $400 \mathrm{mg} / \mathrm{kg}$ doses significantly $(P<0.001)$ restored the haloperidolinduced elevated VCM, TP, and OB (Table 2). At $400 \mathrm{mg} / \mathrm{kg}$, the ethanolic extract had the greatest impact. 
Table 2: Effect of $C$. colocynthis fruit on orofacial dyskinesia in different experimental groups

\begin{tabular}{|c|c|c|c|c|c|c|c|c|c|}
\hline \multirow{3}{*}{ Groups } & \multicolumn{3}{|c|}{ Vacuous Chewing Motion } & \multicolumn{3}{|c|}{ Orofacial Burst } & \multicolumn{3}{|c|}{ Tongue Protrusion } \\
\hline & & & & & Day & & & & \\
\hline & 1 & 7 & 14 & 1 & 7 & 14 & 1 & 7 & 14 \\
\hline $\begin{array}{l}\text { Normal } \\
\text { Control }\end{array}$ & $\begin{array}{l}14 \pm \\
0.05\end{array}$ & $16 \pm 0.07$ & $15 \pm 0.02$ & $\begin{array}{l}5.8 \pm \\
0.08\end{array}$ & $\begin{array}{c}6.3 \pm \\
0.07\end{array}$ & $6 \pm 0.10$ & $\begin{array}{c}3 \pm \\
0.07\end{array}$ & $4 \pm 0.12$ & $\begin{array}{c}2.9 \pm \\
0.09\end{array}$ \\
\hline $\begin{array}{l}\text { Disease } \\
\text { Control }\end{array}$ & $\begin{array}{l}16 \pm \\
0.15\end{array}$ & $92 \pm 0.08^{\alpha}$ & $\begin{array}{l}112 \pm \\
0.07^{\alpha}\end{array}$ & $\begin{array}{l}6.4 \pm \\
0.12 \\
\end{array}$ & $\begin{array}{c}39 \pm \\
0.05^{\alpha}\end{array}$ & $\begin{array}{c}45 \pm \\
0.08^{\alpha}\end{array}$ & $\begin{array}{l}3.5 \pm \\
0.07\end{array}$ & $\begin{array}{c}11 \pm \\
0.11^{\alpha}\end{array}$ & $\begin{array}{c}14 \pm \\
0.10^{\alpha}\end{array}$ \\
\hline $\begin{array}{c}\text { Standard } \\
\text { Control }\end{array}$ & $\begin{array}{l}17 \pm \\
0.15\end{array}$ & $\begin{array}{c}58.75 \pm \\
0.14^{* * *}\end{array}$ & $\begin{array}{c}44.83 \pm \\
0.17^{* * *}\end{array}$ & $\begin{array}{l}5.5 \pm \\
0.12\end{array}$ & $\begin{array}{c}21 \pm \\
0.08^{* * *}\end{array}$ & $\begin{array}{c}15 \pm \\
0.09^{* * *}\end{array}$ & $\begin{array}{c}4 \pm \\
0.14\end{array}$ & $\begin{array}{c}7.5 \pm \\
0.11^{* * *}\end{array}$ & $\begin{array}{c}6.2 \pm \\
0.13^{* * *}\end{array}$ \\
\hline AECC 200 & $\begin{array}{l}16 \pm \\
0.03 \\
\end{array}$ & $\begin{array}{c}112 \pm \\
0.01^{* * *}\end{array}$ & $\begin{array}{c}98 \pm \\
0.08^{* * *}\end{array}$ & $\begin{array}{l}5.1 \pm \\
0.07 \\
\end{array}$ & $\begin{array}{c}35 \pm \\
0.07^{\text {** }} \\
\end{array}$ & $\begin{array}{l}28.5 \pm \\
0.08^{* * *}\end{array}$ & $\begin{array}{c}3 \pm \\
0.11 \\
\end{array}$ & $\begin{array}{l}9.45 \pm \\
0.12^{* *} \\
\end{array}$ & $\begin{array}{c}8.8 \pm \\
0.17^{* * *} \\
\end{array}$ \\
\hline AECC 400 & $\begin{array}{c}14.5 \pm \\
0.05\end{array}$ & $\begin{array}{c}105.67 \pm \\
0.06^{* * *}\end{array}$ & $\begin{array}{l}95.3 \pm \\
0.06^{* * *}\end{array}$ & $\begin{array}{l}4.8 \pm \\
0.14\end{array}$ & $\begin{array}{c}32 \pm \\
0.09^{* * *} \\
\end{array}$ & $\begin{array}{c}27 \pm \\
0.07^{* * *}\end{array}$ & $\begin{array}{l}3.5 \pm \\
0.01\end{array}$ & $\begin{array}{c}8 \pm \\
0.05^{* * *}\end{array}$ & $\begin{array}{c}8.4 \pm \\
0.12^{* * *} \\
\end{array}$ \\
\hline EECC 200 & $\begin{array}{c}15.2 \pm \\
0.17\end{array}$ & $\begin{array}{c}115 \pm \\
0.14^{* * *}\end{array}$ & $\begin{array}{l}88.7 \pm \\
0.06^{* * *}\end{array}$ & $\begin{array}{l}6.2 \pm \\
0.08\end{array}$ & $\begin{array}{c}37 \pm \\
0.07^{* * *}\end{array}$ & $\begin{array}{l}24.2 \pm \\
0.11^{* * *}\end{array}$ & $\begin{array}{l}4.2 \pm \\
0.05\end{array}$ & $\begin{array}{c}8 \pm \\
0.08^{* * *}\end{array}$ & $\begin{array}{c}8.1 \pm \\
0.09^{* * *}\end{array}$ \\
\hline EECC 400 & $\begin{array}{l}15 \pm \\
0.13\end{array}$ & $\begin{array}{c}97 \pm \\
0.14^{* * *}\end{array}$ & $\begin{array}{c}79.35 \pm \\
0.12^{* * *}\end{array}$ & $\begin{array}{l}5.7 \pm \\
0.08\end{array}$ & $\begin{array}{c}28 \pm \\
0.14^{* * *} \\
\end{array}$ & $\begin{array}{c}22 \pm \\
0.13^{* * *}\end{array}$ & $\begin{array}{l}3.8 \pm \\
0.11 \\
\end{array}$ & $\begin{array}{c}7.1 \pm \\
0.09^{* * *}\end{array}$ & $\begin{array}{c}7.7 \pm \\
0.13^{* * *}\end{array}$ \\
\hline
\end{tabular}

The mean and standard error of the mean were used to express all of the data $(n=6)$. Tukey's multiple comparison test was used after the one-way analysis of variance. ${ }^{\alpha} P<0.001$ was found when compared to the normal control group, ${ }^{* * *} P<0.001$ and ${ }^{* *} P<0.01$ were found when compared to the disease control group.

\subsection{Effect of $C$. colocynthis on Catalepsy}

On days 1,7 , and 14 of the experimental period, the cataleptic score of the experimental rats was examined. There was no evidence of catalepsy found in the normal group. When compared to the normal control group, haloperidol administration caused catalepsy and the cataleptic score was significantly $(P<0.001)$ greater in the disease control group. On treatment with standard drug, AECC and EECC extracts at $200 \mathrm{mg} / \mathrm{kg}$ and 400 $\mathrm{mg} / \mathrm{kg}$, only the ethanolic extract at $400 \mathrm{mg} / \mathrm{kg}$ showed a reduced $(P<0.01)$ cataleptic score on the $7^{\text {th }}$ day, which was significantly $(P<0.001)$ reduced further on the $14^{\text {th }}$ day when compared to the disease control group (Figure 1). The ethanolic extract had the greatest impact at $400 \mathrm{mg} / \mathrm{kg}$, which was close to the standard group.

\subsection{Effect of $C$. colocynthis on Locomotor Activity}

Haloperidol significantly $(P<0.001)$ reduced locomotor activity in the disease control group as compared to the normal control group. When compared to the disease control group, treatment with standard medication, AECC, and EECC extracts at 200 and $400 \mathrm{mg} / \mathrm{kg}$ significantly $(P<$ 0.001 ) recovered locomotor activity on the 7 th and $14^{\text {th }}$ days of the trial (Figure 2). The ethanolic extract, which was close to the standard group, had the highest activity at $400 \mathrm{mg} / \mathrm{kg}$.

\subsection{Effect of C. colocynthis on Dopamine Level}

When compared to the normal control group, haloperidol significantly $(P<0.001)$ lowered dopamine levels in disease control animals. When compared to the disease control group, treatment with standard drug, AECC and EECC extracts at 200 and $400 \mathrm{mg} / \mathrm{kg}$ resulted in a substantial rise in dopamine levels. Figure 3 shows that dopamine levels in the AECC and EECC extracts at 200 and $400 \mathrm{mg} / \mathrm{kg}$ were similar to those in the standard carbidopa group, with the ethanolic extract having a greater impact.

\subsection{Effect of $C$. colocynthis on MDA Level}

When compared to the normal control group, haloperidol significantly $(P<0.001)$ lowered SOD levels in disease control animals. When compared to the disease control group, treatment with standard drug, AECC and EECC extracts at 200 and $400 \mathrm{mg} / \mathrm{kg}$ resulted in a significant $(P<0.001)$ rise in SOD levels. As shown in Figure 3, SOD levels in the AECC and EECC extracts at 200 and $400 \mathrm{mg} / \mathrm{kg}$ were similar to those in the standard carbidopa group, with the ethanolic extract having a greater impact. 
Figure 1: Effect of C. colocynthis fruit on behavioral parameters of different experimental groups
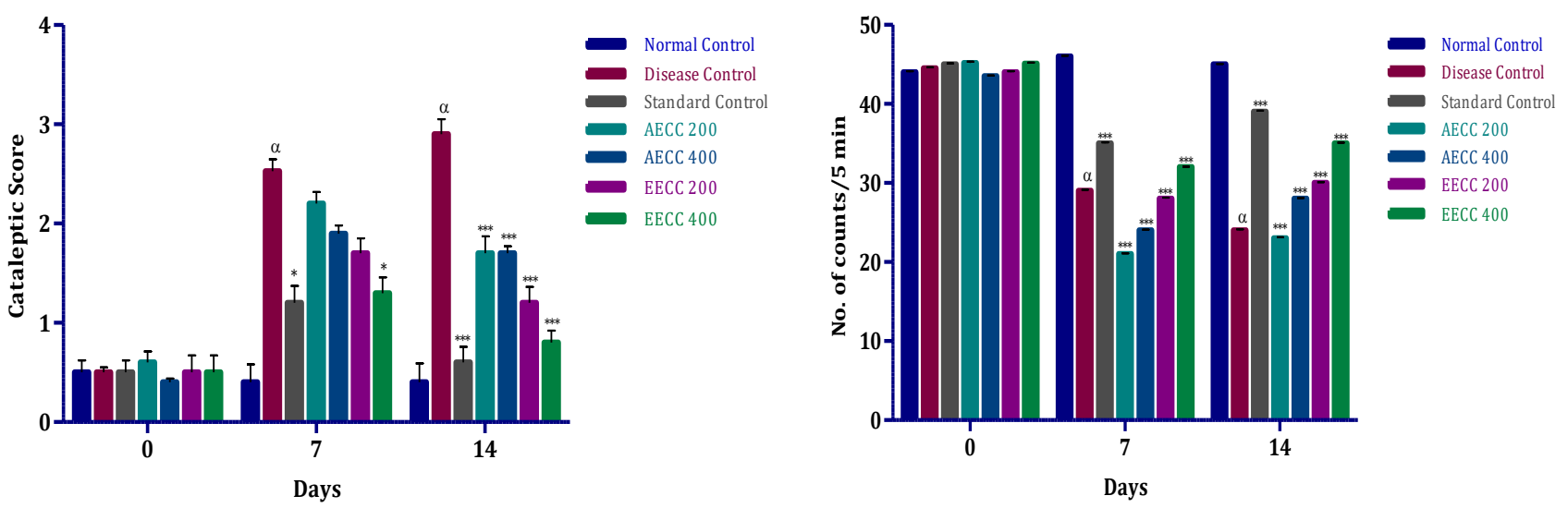

Effect of AECC and EECC on (a) cataleptic score (b) locomotor activity in experimental rats. The mean and standard error of the mean $(n=6)$ were used to express all of the data. Tukey's multiple comparison test was used after one-way analysis of variance. ${ }^{\alpha} P<0.001$ was found when compared to the normal control group, ${ }^{* * *} P<0.001$ and ${ }^{*} P<0.05$ were found when compared to the disease control group.

\subsection{Effect of $C$. colocynthis on SOD Level}

When compared to the normal control group, haloperidol significantly $(P<0.001)$ lowered SOD levels in disease control animals. When compared to the disease control group, treatment with standard drug, AECC and EECC extracts at
200 and $400 \mathrm{mg} / \mathrm{kg}$ resulted in a significant $(P<$ 0.001 ) rise in SOD levels. As shown in Figure 3, SOD levels in the AECC and EECC extracts at 200 and $400 \mathrm{mg} / \mathrm{kg}$ were similar to those in the standard carbidopa group, with the ethanolic extract having a greater impact.

Figure 3: Effect of $C$. colocynthis fruit on biochemical parameters of different experimental groups
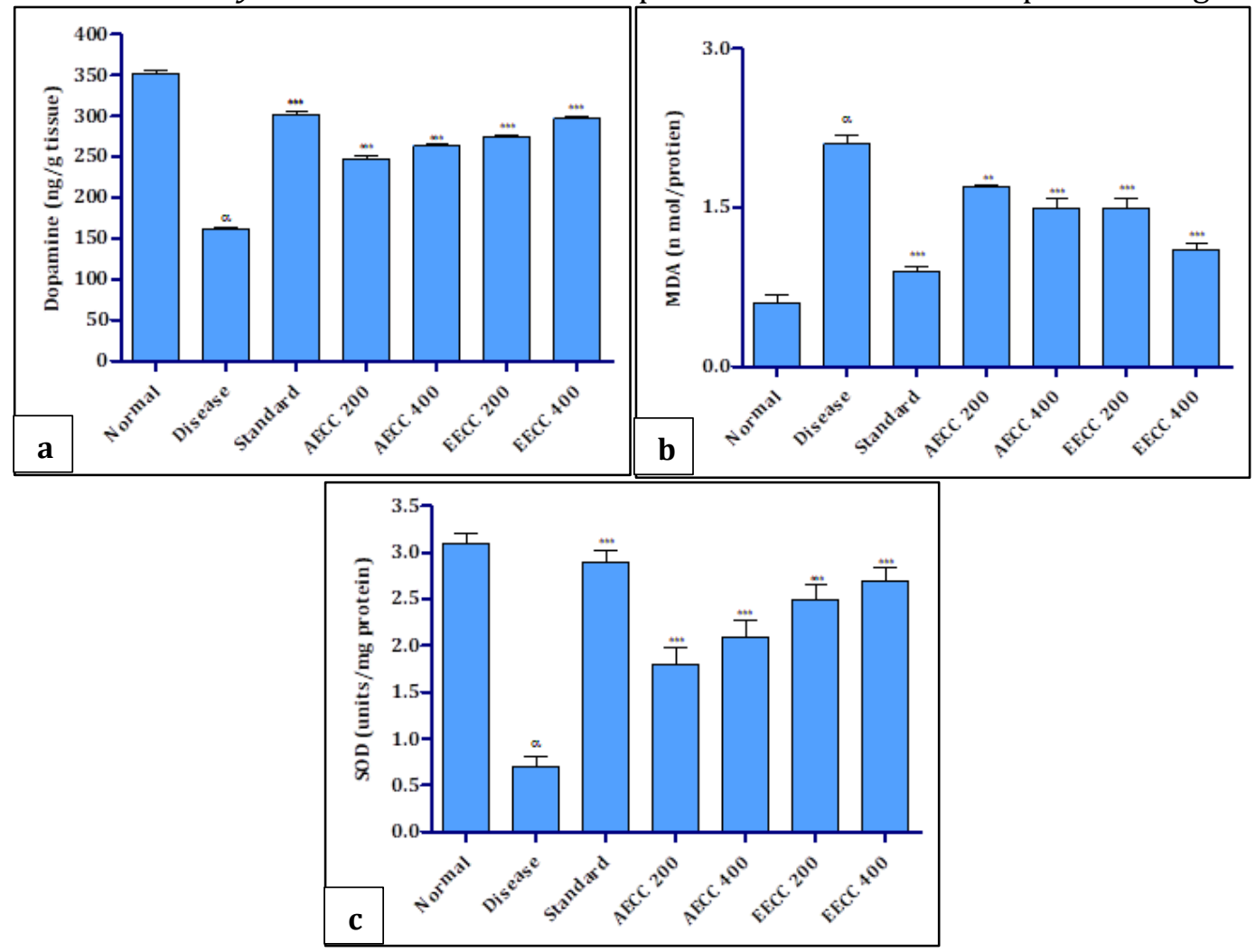

Effect of AECC and EECC on (a) DA, (b) MDA, (c) SOD. The mean and standard error of the mean (n=6) were used to express all of the data. Tukey's multiple comparison test was used after one-way analysis of variance. ${ }^{\alpha} P<0.001$ was found when compared to the normal control group, ${ }^{* *} P<0.001$ and ${ }^{* *} P<0.01$ was found when compared to the disease control group. 


\section{DISCUSSION}

Parkinson's disease is a chronic neurodegenerative condition marked by the death of SNpc dopamine neurons. Mitochondrial dysfunction, protein buildup such as $\alpha$-synuclein, oxidative stress, necrosis, and neuronal excitotoxicity are all causes of the PD pathogenesis. Among these, oxidative stress is a critical pathogenic process in Parkinson's disease. ${ }^{33}$ Because the basal ganglia in the brain utilize a lot of energy and have a lot of polyunsaturated fatty acids, they are particularly sensitive to free radical overproduction produced by accelerated dopamine circulation. ${ }^{34}$

The current study evaluated the effect of aqueous and ethanolic fruit extracts of $C$. colocynthis in haloperidol induced Parkinson disease in Wistar rats. Preliminary qualitative phytochemical analysis made for the fruit of $C$. colocynthis revealed the presence of tannins, phenols, saponins, terpenoids, flavonoids, steroids, carbohydrates, glycosides, ssaponins and proteins. Because these secondary metabolites are said to have a wide range of biological and pharmacological activities, this species is believed to have a various medical applications. ${ }^{35}$ The extraction yield of water and ethanolic extracts of C. colocynthis fruit shown that the ethanol extract had a greater percentage of yield. It might be owing to the ethanolic solvent's strong polarity, which allows it to attract a greater diversity of plant elements than other solvents. ${ }^{36}$

Haloperidol-induced catalepsy is a well-known animal model of Parkinson's disease. By interacting with catecholamine storage intracellularly, haloperidol creates a pharmacological model of Parkinsonism, leading in dopamine depletion in nerve terminals. ${ }^{37}$ Increased frequency of VCM, OB and TP was observed in rats treated with haloperidol. Treatment with AECC and EECC at doses of 200 and $400 \mathrm{mg} / \mathrm{kg}$ significantly inhibited the haloperidol-induced VCM, OB and TP. The ethanolic extract has high effect in lowering the symptoms of orofacial dyskinesia than the aqueous extract. Haloperidol $(1 \mathrm{mg} / \mathrm{kg}$, i.p.) caused substantial catalepsy in rats in the current investigation, as demonstrated by a considerable increase in the duration spent on the block when compared to normal control animals.

In haloperidol-treated rats, treatment with aqueous and ethanolic fruit extracts of $C$. colocynthis dramatically decreased catalepsy in a dose-dependent manner. The AECC and EECC displayed protective effects towards haloperidolinduced catalepsy at dosages of 200 and 400 $\mathrm{mg} / \mathrm{kg}$, indicating that this plant can protect dopaminergic neurotransmission in the striatum. In addition, Chen et al., 2019 showed that the $C$. colocynthis extract may ameliorate the pathogenic condition of PD in MPP+ cell model and MPTP animal model in a prior research work. ${ }^{38}$

Another key aspect of measuring the potential of CNS drug is observing the animal's locomotor activity. CNS depression causes reduced activity, which is a measure of the amount of reactivity of the CNS. ${ }^{39}$ In the present experimental study, locomotor activity was performed with actophotometer to examine haloperidol-induced PD in rats. According to the findings of the actophotometer test, the extract considerably reduced locomotor activity.

Dopamine reduction was a prominent symptom and also a biomarker in the identification of Parkinson's disease. The intoxication of dopaminergic neurons by haloperidol is thought to be a probable aetiology of Parkinson's disease. The degeneration of dopaminergic neurons causes a drop in dopamine and its metabolites levels. The elevated dopamine levels caused by haloperidol administration might be attributable to reduced dopamine metabolism or enhanced dopamine production by the dopaminergic neurons. ${ }^{40}$ The treatment with AECC and EECC at doses of 200 and $400 \mathrm{mg} / \mathrm{kg}$ showed increased dopamine levels when compared to the disease control group. Based upon our results, it is best evidenced that ethanolic extract of $C$. colocynthis fruit have more dopamine increasing potential than the aqueous extract.

The pathophysiology of PD is complicated by oxidative stress caused by mitochondrial 
malfunction, especially mitochondrial complex-1 impairment. The amounts of malondialdehyde (MDA), catalase (CAT), superoxide dismutase (SOD), and reduced glutathione in the brain tissue were used to assess oxidative stress. ${ }^{33}$ In the present research, haloperidol results in an increase in the formation of hydrogen peroxide and free radicals, as evidenced by increased MDA levels.

Reactive oxygen species cause lipid peroxidation that is described by the development of MDA, a primary result of lipid peroxidation that forms complex with DNA bases and proteins, producing cell damage. The brains of PD patients have been found to have higher levels of oxidative damage to DNA, peptides, and fats, as well as lower levels of antioxidants. ${ }^{41}$

When compared with normal control rats, the haloperidol-treated disease group had relatively high levels of MDA. In contrast to the haloperidolinduced illness group, AECC and EECC treatment at dosages of 200 and $400 \mathrm{mg} / \mathrm{kg}$ substantially reduced MDA levels. Inhibition of lipid peroxidation by AECC and EECC in the current study might have been mediated by the detoxification of peroxy radicals and reactive oxygen, indicating an antioxidative activity. SOD is one of the most critical enzymes in the body's antioxidant defence system. The major function of SOD is to catalyse the conversion of superoxide anion radicals to $\mathrm{H}_{2} \mathrm{O}_{2}$ and hence reduces the toxic effects due to this radical or other free radicals derived from secondary reactions. In this study, a significant decrease in the concentration of SOD level was observed in haloperidol treated disease group. ${ }^{42}$

The antioxidant enzyme levels were considerably reversed after treatment with AECC and EECC at dosages of 200 and $400 \mathrm{mg} / \mathrm{kg}$, respectively. A reduction in SOD activity can lead to a reduction in superoxide ion elimination, which can be detrimental to the organs. ${ }^{43}$ Furthermore, the improved SOD activity in AECC and EECC at doses of 200 and $400 \mathrm{mg} / \mathrm{kg}$ groups might involve in the scavenging of $\mathrm{O}_{2}$ generated from haloperidol, specially the ethanolic extract. There is strong consensus that flavonoids operate as reactive oxygen species scavengers. ${ }^{4}$

The neuroprotective and antiparkinson activity of Citrullus colocynthis may be due to its antioxidant property. The above behavioral and biochemical results suggest that $C$. colocynthis has the ability to improve symptoms of PD, in part, by the restoring the level of dopamine, and by the regulation of the antioxidant system. Hence, $C$. colocynthis may be useful as a neuroprotective agent in the treatment of PD. The above observed beneficial effects of $C$. colocynthis may be attributed to diverse chemical components found in the fruit, namely flavonoids, alkaloids, saponins, and phenols.

\section{CONCLUSION}

In view of the above facts, the present study concludes that aqueous and ethanolic extracts of Citrullus colocynthis (L.) Schrad fruit possess antioxidant activity and showed a promising effect in animals with Parkinson's disease. Research should focus on elucidating the molecular basis of pharmacological action. A systemic research is needed to produce a therapeutic drug from fruits of Citrullus colocynthis for neuroprotection.

Acknowledgement: The authors are appreciative to Dr. D. Ramakrishna, Principal, Shadan Women's College of Pharmacy, Hyderabad, Telangana, India for his invaluable assistance during this study.

Conflict of Interest: There are no conflicts of interest among the authors.

Source of Support: The study was supported by the Shadan Educational Society (SES), Hyderabad, India.

\section{REFERENCES}

1. Alexander GE. Biology of Parkinson's disease: pathogenesis and pathophysiology of a multisystem neurodegenerative disorder. Dialogues Clin Neurosci. 2004 Sep;6(3):259-80.

2. DeMaagd G, Philip A. Parkinson's Disease and Its Management: Part 1: Disease Entity, Risk Factors, Pathophysiology, Clinical Presentation, and 
Diagnosis. P T. 2015 Aug;40(8):504-32.

3. Zafar S, Yaddanapudi SS. Parkinson Disease. StatPearls. Treasure Island (FL): StatPearls Publishing; 2021 Jan. Available from: https://www.ncbi.nlm.nih.gov/books/NBK470193

4. Bloem BR, Okun MS, Klein C. Parkinson's disease. Lancet. 2021 Jun 12;397(10291):2284-2303.

5. Balestrino R, Schapira AHV. Parkinson disease. Eur J Neurol. 2020 Jan;27(1):27-42.

6. Dorsey ER, Elbaz A, Nichols E, Abd-Allah F, Abdelalim A, Adsuar JC, Ansha MG, Brayne C, Choi J-YJ, Collado-Mateo D, Dahodwala N, Do HP, Edessa $D$, Endres $\mathrm{M}$, Fereshtehnejad S-M, Foreman KJ, Gankpe FG, Gupta R, Hankey GJ, Hay SI, Hegazy MI, Hibstu DT, Kasaeian A, Khader Y, Khalil I, Khang YH, Kim YJ, Kokubo Y, Logroscino G, Massano J, Mohamed Ibrahim N, Mohammed MA, Mohammadi A, Moradi-Lakeh M, Naghavi M, Nguyen BT, Nirayo YL, Ogbo FA, Owolabi MO, Pereira DM, Postma MJ, Qorbani M, Rahman MA, Roba KT, Safari H, Safiri S, Satpathy M, Sawhney M, Shafieesabet A, Shiferaw MS, Smith M, Szoeke CEI, Tabarés-Seisdedos R, Truong NT, Ukwaja KN, Venketasubramanian N, Villafaina $\mathrm{S}$, weldegwergs $\mathrm{K}$ gidey, Westerman $\mathrm{R}$, Wijeratne T, Winkler AS, Xuan BT, Yonemoto N, Feigin VL, Vos T, Murray CJL. Global, regional, and national burden of Parkinson's disease, 19902016: a systematic analysis for the Global Burden of Disease Study 2016. The Lancet Neurology. Elsevier BV; 2018 Nov;17(11):939-953.

7. Dias V, Junn E, Mouradian MM. The role of oxidative stress in Parkinson's disease. J Parkinsons Dis. 2013;3(4):461-91.

8. Park HA, Ellis AC. Dietary Antioxidants and Parkinson's Disease. Antioxidants (Basel). 2020 Jul 1;9(7):570.

9. Hantikainen E, Lagerros YT, Ye W, Serafini M, Adami H-O, Bellocco R, Bonn S. Dietary antioxidants and the risk of Parkinson Disease. Neurology. Ovid Technologies (Wolters Kluwer Health); 2021 Jan 6.

10. Jin H, Kanthasamy A, Ghosh A, Anantharam V, Kalyanaraman B, Kanthasamy AG. Mitochondriatargeted antioxidants for treatment of Parkinson's disease: Preclinical and clinical outcomes. Biochimica et Biophysica Acta (BBA) - Molecular Basis of Disease. Elsevier BV; 2014 Aug;1842(8):1282-1294.
11. Dong J, Cui Y, Li S, Le W. Current Pharmaceutical Treatments and Alternative Therapies of Parkinson's Disease. Curr Neuropharmacol. 2016;14(4):339-55.

12. Anand U, Jacobo-Herrera N, Altemimi A, Lakhssassi N. A Comprehensive Review on Medicinal Plants as Antimicrobial Therapeutics: Potential Avenues of Biocompatible Drug Discovery. Metabolites. 2019 Nov 1;9(11):258.

13. Johnson SL, Kirk RD, DaSilva NA, Ma H, Seeram NP, Bertin MJ. Polyphenol Microbial Metabolites Exhibit Gut and Blood ${ }^{-}$Brain Barrier Permeability and Protect Murine Microglia against LPS-Induced Inflammation. Metabolites. 2019 Apr 19;9(4):78.

14. Ekor M. The growing use of herbal medicines: issues relating to adverse reactions and challenges in monitoring safety. Front Pharmacol. 2014 Jan 10;4:177.

15. Kapoor M, Kaur N, Sharma C, Kaur G, Kaur R, Batra $\mathrm{K}$ and Rani J. Citrullus colocynthis an Important Plant in Indian Traditional System of Medicine. Pharmacog Rev. 2020 June;14(27):22-7.

16. Rahimi R, Amin G, Ardekani MR. A review on Citrullus colocynthis Schrad.: from traditional Iranian medicine to modern phytotherapy. J Altern Complement Med. 2012 Jun;18(6):551-4.

17. Nayab D, Ali D, Arshad N, Malik A, Choudhary MI, Ahmed Z. Cucurbitacin glucosides from Citrullus colocynthis. Nat Prod Res. 2006 May 10;20(5):40913.

18. Ghauri AO, Ahmad S, Rehman T. In vitro and in vivo anti-diabetic activity of Citrullus colocynthis pulpy flesh with seeds hydro-ethanolic extract. J Complement Integrat Med. 2020 Jan 23; 17(2): 20180228.

19. Meybodi MSK. A Review on Pharmacological Activities of Citrullus colocynthis (L.) Schrad. Asian J Res Reports Endocrin. 2020 June 25;3(1):25-34.

20. Oryan A, Hashemnia M, Hamidi AR, Mohammadalipour A. Effects of hydro-ethanol extract of Citrullus colocynthis on blood glucose levels and pathology of organs in alloxan-induced diabetic rats. Asian Pac J Trop Dis. 2014 Apr;4(2):125-30.

21. Gul R, Jan SU, Faridullah S, Sherani S, Jahan N. Preliminary Phytochemical Screening, Quantitative Analysis of Alkaloids, and Antioxidant Activity of Crude Plant Extracts from Ephedra 
intermedia Indigenous to Balochistan. Sci World J. 2017 Mar 13:5873648.

22. OECD, OECD guidelines for the testing of chemicals/section 4: Health effects test no 423: Acute oral toxicity - Acute toxic class method. OECD; Paris: 2002.

23. Jonsson $M$, Jestoi $M$, Nathanail AV, Kokkonen UM, Anttila M, Koivisto P, Karhunen P, Peltonen K. Application of OECD Guideline 423 in assessing the acute oral toxicity of moniliformin. Food Chem Toxicol. 2013 Mar;53:27-32.

24. Khisti RT, Mandhane SN, Chopde CT. Haloperidolinduced catalepsy: a model for screening antidepressants effective in treatment of depression with Parkinson's disease. Indian J Exp Biol. 1997 Dec;35(12):1297-301.

25. Cousins MS, Carriero DL, Salamone JD. Tremulous jaw movements induced by the acetylcholinesterase inhibitor tacrine: effects of antiparkinsonian drugs. Eur J Pharmacol. 1997 Mar 19;322(2-3):137-45.

26. Bishnoi M, Chopra K, Kulkarni SK. Involvement of adenosinergic receptor system in an animal model of tardive dyskinesia and associated behavioural, biochemical and neurochemical changes. Eur J Pharmacol. 2006 Dec 15;552(1-3):55-66.

27. Makhija DT, Jagtap AG. Studies on sensitivity of zebrafish as a model organism for Parkinson's disease: Comparison with rat model. J Pharmacol Pharmacother. 2014 Jan;5(1):39-46.

28. Kulkarni SK. Experimental pharmacology. 3rd Ed. New Delhi: Vallabh Prakashan. 2005;117-8.

29. Nade VS, Kawale LA, Zambre SS, Kapure AB. Neuroprotective potential of Beta vulgaris L. in Parkinson's disease. Indian J Pharmacol. 2015 JulAug;47(4):403-8.

30. Manikkoth S, Deepa B, Sequeira M, Joy AE, Rodrigues R. Assessment of brain dopamine levels to evaluate the role of Tylophora indica ethanolic extract on alcohol induced anxiety in wistar albino rats. J Young Pharm. 2016 Jan;8:915.

31. Ohkawa H, Ohishi N, Yagi K. Assay for lipid peroxides in animal tissues by thiobarbituric acid reaction. Anal Biochem. 1979 Jun;95(2):351-8.

32. Kono Y. Generation of superoxide radical during autoxidation of hydroxylamine and an assay for superoxide dismutase. Arch Biochem Biophys. 1978 Feb;186(1):189-95.

33. Dias V, Junn E, Mouradian MM. The role of oxidative stress in Parkinson's disease. J Parkinsons Dis. 2013;3(4):461-91.

34. Patil R, Dhawale K, Gound H, Gadakh R. Protective Effect of Leaves of Murraya koenigii on ReserpineInduced Orofacial Dyskinesia. Iran J Pharm Res. 2012 Spring;11(2):635-41.

35. Seca AML, Pinto DCGA. Biological Potential and Medical Use of Secondary Metabolites. Medicines (Basel). 2019 Jun 12;6(2):66.

36. Altemimi A, Lakhssassi N, Baharlouei A, Watson DG, Lightfoot DA. Phytochemicals: Extraction, Isolation, and Identification of Bioactive Compounds from Plant Extracts. Plants (Basel). 2017 Sep 22;6(4):42.

37. Waku I, Magalhães MS, Alves CO, de Oliveira AR. Haloperidol-induced catalepsy as an animal model for parkinsonism: A systematic review of experimental studies. Eur J Neurosci. 2021 Jun;53(11):3743-3767.

38. Chen Y, Sa Y, Wang G, Pan X, Zhen Y, Cheng X, Zhang K, Fu L, Wang H, Liu B. The protective effects of Citrullus colocynthis on inhibiting oxidative damage and autophagy-associated cell death in Parkinson's disease. J Taiwan Inst Chem Eng. 2019;100(9680):18-25.

39. Bhosale UA, Yegnanarayan R, Pophale PD, Zambare MR, Somani RS. Study of central nervous system depressant and behavioral activity of an ethanol extract of Achyranthes aspera (Agadha) in different animal models. Int J Appl Basic Med Res. 2011 Jul;1(2):104-8.

40. Duty S, Jenner P. Animal models of Parkinson's disease: a source of novel treatments and clues to the cause of the disease. Br J Pharmacol. 2011 Oct;164(4):1357-91.

41. Ayala A, Muñoz MF, Argüelles S. Lipid peroxidation: production, metabolism, and signaling mechanisms of malondialdehyde and 4-hydroxy-2-nonenal. Oxid Med Cell Longev. 2014;2014:360438.

42. Younus H. Therapeutic potentials of superoxide dismutase. Int J Health Sci (Qassim). 2018 MayJun;12(3):88-93.

43. Wang Y, Branicky R, Noë A, Hekimi S. Superoxide dismutases: Dual roles in controlling ROS damage 
and regulating ROS signaling. J Cell Biol. 2018 Jun 4;217(6):1915-1928.
44. Kumar S, Pandey AK. Chemistry and biological activities of flavonoids: an overview. Sci World J. 2013 Dec 29;2013:162750.

Cite the Article as: Nimra F, Fatima N. Evaluation of Neuroprotective and Antiparkinson's Activity of Citrullus colocynthis Fruit. J Drug Vigil Altern Ther. 2021 June 30;1(2):78-88.

\section{www.jdvat.org}

(cc) EY-NC-SA This is an open access paper distributed under the copyright agreement with JDVAT, which permits noncommercial unrestricted use, distribution, and reproduction in any medium or format, provided the original work is properly cited. 